\title{
Performance of growing pigs reared indoors or outdoors in sweet-potato fields*
}

\author{
Jean-Luc Gourdine $^{1 * *}$ Jean-Christophe Bambou ${ }^{1}$ \\ Mario Giorgi² Gladys Loranger-Merciris ${ }^{3,4}$ Harry Archimède ${ }^{1}$
}

\section{Keywords}

Swine, animal husbandry, animal feeding, growth, sweet potato, Guadeloupe

Submitted: 31 August 2017

Accepted: 24 October 2017

Published: 9 July 2018

DOI: $10.19182 /$ remvt.31347

\begin{abstract}
Summary
The study aimed to evaluate the effect of the genetic type (Large White [LW] vs Creole [CR]) and feeding management (indoors with concentrate [CSC], outdoors on sweet potato plots [OSP], indoors with the same ration as outdoors [CSP]) on 54 growing pigs. OSP animals had a growth rate of 240 grams per day, compared to 360 and $580 \mathrm{~g} / \mathrm{d}$ for CSP and CSC pigs, respectively $(\mathrm{p}<0.001$ ). Outdoors, LWs were more physically active than CRs $(15 \%$ of the time in exploratory activities vs $10 \%$, respectively; $\mathrm{p}<0.01)$. The distances covered over 24 hours were 90 meters for CRs and 150 meters for LWs $(p<0.01)$. Blood profiles suggested a faster adaptive hematological response of CRs to system change (from indoors to outdoors). The study of soil macrofauna after passage of animals showed an increase on the grazed plots in macroinvertebrates (notably Oligochaeta, Dermaptera) that decompose organic matter. This study suggests that alternative livestock systems, although less efficient, may meet farmers' needs for economic gain in animal production, using agricultural residues or minimizing human intervention.
\end{abstract}

- How to quote this article: Gourdine J.-L., Bambou J.-C., Giorgi M., Loranger-Merciris G., Archimède H., 2018. Performance of growing pigs reared indoors or outdoors in sweet-potato fields. Rev. Elev. Med. Vet. Pays Trop., 71 (1-2): 41-46, doi: 10.19182/remvt.31347

\section{INTRODUCTION}

In Guadeloupe, pig production is based on a variety of farming systems, from the specialized industrial systems based on imported feed and breeds to the small family pig farming systems which depend highly on the biodiversity available in their environment (Gourdine et al., 2011). In simplified terms, there are two contrasted logics of production. In industrial systems, the logic is 'what to do' to maximize the pig output/input ratio, whereas in non-conventional systems, such as pig production in mixed farming systems, the logic is more "what to

\footnotetext{
1. INRA, UR0143 URZ, Domaine Duclos Prise d'Eau, 97170 Petit-Bourg, Guadeloupe.

2. INRA, UE503 PTEA, Petit-Bourg, Guadeloupe.

3. Université des Antilles, UFR Sciences exactes et naturelles, Pointe-à-Pitre, Guadeloupe.

4. INRA, UR1321 ASTRO, Petit-Bourg, Guadeloupe.

** Corresponding author

Tel.: +590 (0) 5902559 42; Fax: +590 (0) 590255936

Email: jean-luc.gourdine@inra.fr
}

do with' the available biomass from the farm or neighboring farms to limit inputs. These two logics are not mutually exclusive and, in some cases, they can support each other.

Irrespective of the type of pig production system, feed is the costliest element in the production (around $60 \%$ to $70 \%$ of the total cost of producing pigs). Farmers seek out alternative feeding solutions to replace partially or totally industrial concentrates by the use of local resources. Similarly, pig farmers in mixed-farming systems seek out alternative rearing systems that limit the cost of production. Small outdoor fattening pig production is known to be a low-input solution that can suit farmers looking for a low initial investment in the infrastructure or manure handling. This way of rearing pigs is rare in Guadeloupe although it is rather common to see pigs individually tied up to a tree (usually a mango tree) in the countryside. To the best of our knowledge, little has been published on outdoor pig production in small-scale farms in tropical humid conditions.

The sweet potato (Ipomea batatas [L.] Lam) has a high nutritional value (leaves are high in proteins, tubers in energy) and is highly palatable

* Preliminary results of this study (on 30 animals) were published in the "Journées Recherche Porcine" (Baudet et al., 2015). 
to pigs (Régnier 2011). Because of the major role of sweet potatoes in tropical agriculture, this plant could be an interesting pig feed alternative (FAOSTAT, 2015). A previous study has shown the feasibility of outdoor pig rearing on a sweet-potato field (Burel et al., 2013). Therefore, the present study was carried out to compare the effects of three pig livestock systems and two breeds on the growth performance, thermoregulatory responses and behavior of fattening pigs under tropical conditions. We aimed to characterize the feeding behavior, activities, growth rate, physiological responses of growing pigs in indoor and outdoor systems, and the impact on soil quality for the latter system.

\section{MATERIALS AND METHODS}

All measurements and observations on animals were carried out in accordance with the current law on animal experimentation and ethics (69-2012-2 from the Animal Care and Use Committee of French West Indies and Guyana) under the direction of J. Fleury (authorization number from the French Ministry of Agriculture and Fisheries 971-2011-03 7704).

\section{Animals and site}

Two trials involving in total 54 fattening pigs (28 females and 26 castrated males) were conducted in experimental facilities of the Tropical Platform for Animal Experimentation (PTEA) of the French National Institute for Agricultural Research (INRA), in Guadeloupe $\left(16^{\circ} 11^{\prime} \mathrm{N}, 61^{\circ} 39^{\prime} \mathrm{W}\right)$. In the first trial, 30 pigs, 15 exotic Large White (LW) and 15 local Creole (CR) were used. In the second trial, 24 pigs, $12 \mathrm{LW}$ and $12 \mathrm{CR}$ were used. These pigs of 12.5 weeks of age were divided into three similar groups in order to maximize the genetic origin; the mean weight was $30.5 \pm 5.0 \mathrm{~kg}$. The first trial was conducted in Mr. G. Magdeleine's outdoor mixed farming system located
18 kilometers away from PTEA, and indoors in PTEA building (Baudet et al., 2015). The second experiment was conducted outdoors and indoors at the experimental facilities of INRA-PTEA.

\section{Experimental design and feeding program}

For technical reasons, the experiment was carried out in 28 days including four days to adapt to the new rearing conditions (outdoors and/or feed). The pigs were reared outdoors in a sweet-potato field $(n=16)$, or indoors on a diet based on sweet potatoes $(n=20)$, or indoors with industrial concentrates $(n=18)$. The three groups corresponded to three farming conditions (Table I).

The first system was conventional and industrial concentrates were used (CSC). Pigs were reared in two pens in a semi-open building. Each pen was equipped with nipple drinkers and animals had free access to water and were fed ad libitum with the commercial diet presented as pellets and formulated to meet the nutritional requirements of growing pigs according to standard recommendations (Noblet et al., 2004). Expressed in percentages of dry matter, the commercial diet was characterized by $15.9 \%$ of crude protein, $5.5 \%$ of ash, $2.6 \%$ of crude fiber, $11.4 \%$ of neutral detergent fiber (NDF), $2.3 \%$ of fat and $46.3 \%$ of starch, leading to an energy value of $13.87 \mathrm{MJ} / \mathrm{kg}$.

The second system was outdoors (OSP) and managed on a sweet-potato field ( $\left.4.7 \mathrm{~m}^{2} / \mathrm{pig} / \mathrm{day}\right)$. OSP pigs fed themselves on sweet-potato leaves and tubers. In a preliminary analysis, 47 samples of tubers and leaves were collected $\left(0.5 \mathrm{~m}^{2} / 19 \mathrm{~m}^{2}\right)$ in order to evaluate the available amount of sweet potatoes; It was estimated to be on average $6 \mathrm{~kg}$ fresh weight/pig/day. Thus, animals were considered to have more than the amount of sweet potatoes required to cover energy needs. On average $1.2 \mathrm{~kg} / \mathrm{pig} / \mathrm{day}$ of fresh leaves were available but the 47 samples of leaves showed a lack of protein for their diet. Therefore, pigs were given soybeans as supplementation at the end of the afternoon (at

Table I

Experimental design of the three pig rearing systems (Guadeloupe)

CSC

10 in trial $1+8$ in trial 2

Commercial diet

Indoors
CSP

12 in trial $1+8$ in trial 2

Sweet-potato tubers and leaves

Soybean meal supplement

Indoors
OSP

8 in trial $1+8$ in trial 2

\section{Rearing system}

Diet

Building

\section{Measurements per animal}

Production

Body weight (day-4, d-1, d11 and

d25)

Average back-fat thickness at $\mathrm{d} 25$

d25

Average back-fat thickness at d25

Thermoregulation

Rectal and average skin temperature (d-4, d- $1, \mathrm{~d} 11$ and d25)

Rectal and average skin temperatures $(\mathrm{d}-4, \mathrm{~d}-1$, d 11 and d25)

Samples collected in trial 2 Blood samples for hematology characteristics (d-4, d1, d11 and d22)
Blood samples for hematology characteristics (d-4, d1, d11 and d22)
Free access to sweet-potato tubers and leaves

Soybean meal supplement

Outdoors 
around 17:00). The provided amount of protein supplement was calculated to fulfill the nutritional requirements to achieve in theory a growth rate of $500 \mathrm{~g} /$ day for CR and $800 \mathrm{~g} /$ day for $\mathrm{LW}$.

In order to study the outdoor behavior of each breed, LW and CR were reared separately. The sweet-potato field was divided into 2 × 24 small plots of $19 \mathrm{~m}^{2}$. Every day, pigs grazed on a different plot, with an access to the last and one before last plots $\left(37 \mathrm{~m}^{2}\right.$ the second day and $56 \mathrm{~m}^{2}$ from the third day on) so that the average grazing surface per pig was $4.7 \mathrm{~m}^{2}$ per day. An electric fence delimiting the entire field separated the pigs from potential predators such as dogs. Each small plot within the field was also delimited by electric fencing. A solar-powered battery provided the electricity. Every morning (at about 07:00) one plot per breed was opened to give access to four pigs to sweet-potato leaves and tubers. The four days of adaptation consisted in accustoming pigs to eat sweet potatoes and leaves at first, then to dig the soil to catch sweet-potato tubers. The study showed that four days were enough to make pigs dig for sweet potatoes because of the natural behavior of pigs to root (Burel et al., 2013).

The third system (CSP) was managed in a semi-open building with a diet similar to that of OSP conditions. CSP pigs had ad libitum access to sweet-potato tubers and the same daily average amount of sweet-potato leaves as that available for pigs in OSP. Similarly to OSP pigs, CSP pigs were given soybean meal as supplementation at the end of the afternoon (at around 17:00). LW and CR were reared separately in order to evaluate the effect of breed on growth performance.

\section{Measurements}

\section{Climatic conditions}

In OSP conditions, the rainfall level was recorded daily. The humidity and ambient temperature were recorded twice a day: in the morning (06:00) and at the end of the afternoon (17:00). In indoor conditions (CSC and CSP) the ambient temperature and relative humidity were recorded automatically every 30 minutes, using Campbell Weather Station (Campbell Scientific, Shepshed, UK).

\section{Animal measurements}

Pigs were weighed at the beginning (d-4) and at the end (d-1) of the adaptation period as well as in the middle (d11) and at the end of the experiment (d25). At the end of the study, back-fat thickness of all pigs was evaluated as the average of four ultrasonic measurements (Honda, HS 1500) taken at shoulder and mid-back (P2 site), five centimeters off the midline on each side of the pig. Rectal and skin temperatures (three measurements: back, side and skull) were recorded for all pigs at the beginning (d-4) and at the end (d-1) of the adaptation period as well as in the middle (d11) and at the end of the experiment (d25). Digital thermometers (Microlife, Paris, France) were used to measure rectal temperatures, and skin temperatures were measured using an infrared thermometer (Omega, Stamford, CT, USA).

\section{Measurements and samples collected in the outdoor system}

The outdoor behavior of the pigs was studied twice, near the middle (d7) and the end of the experiment (d19). During 24 continuous hours and every five minutes, the physical activity, feeding behavior and position of each pig in the field area were recorded. Data collected were used to estimate the covered distance in 24 hours by each pig. In the second trial, blood samples were collected before the adaptation (d-4), one day after adaptation (d1), in the middle of the experiment (d11) and toward the end (d22). Blood samples were used to determine hematological characteristics of pigs. Twenty samples of $0.02 \mathrm{~cm}^{3}$ of soil were collected to detect the macrofauna (10 before the arrival of the pigs and 10 after their departure). The soil was sampled using a frame $(25 \times 25 \times 30 \mathrm{~cm})$ and a spade, then the macrofauna was separated from the soil. The macrofauna collected in each sample was kept in 150 -ml bottles containing $70^{\circ}$ alcohol. The taxonomic groups of the macrofauna and the number of individuals per group in each bottle were determined.

\section{Calculations and statistical analyses}

A thermal humidity index (THI) was calculated for each day based on the following formula from the US National Oceanic and Atmospheric Administration (1976, cited by Zumbach et al. [2008]):

$\mathrm{THI}\left({ }^{\circ} \mathrm{C}\right)=\mathrm{T}-(0.55-0.0055 \times \mathrm{RH}) \times(\mathrm{T}-14.5)$

where $\mathrm{T}$ is the average daily ambient temperature $\left({ }^{\circ} \mathrm{C}\right)$ and $\mathrm{RH}$ the average daily relative humidity (\%).

The average daily weight gain between the beginning and the end of the experiment was computed. Data on production traits (average daily gain, initial and final body weights, final back-fat thickness) were analyzed using a linear model (GLM procedure, SAS version 9.4, Cary, $\mathrm{NC}, \mathrm{USA}$ ) with the fixed effects of the system $(\mathrm{n}=3, \mathrm{CSC}, \mathrm{CSP}$ and OSP), the breed ( $n=2, C R$ vs $L W$ ) and their interactions as main effects. The same models were used to analyze outdoor pigs' behavior (time spent in physical or feeding activities), without taking into account the system as fixed effect. Longitudinal records (skin and rectal temperatures) were analyzed using a mixed linear model (Mixed Procedure, vers. 9.4, Cary) with the same fixed effects as those of the linear model, adding the effects of the day and THI. The random effect of the animal was included to account for repeated measurements on the same pig. Least square means of the effects were computed and the differences between the level effects were tested with Tukey test.

\section{RESULTS}

\section{Climatic parameters}

The average ambient temperature and relative humidity in the outdoor system were $27.4^{\circ} \mathrm{C}$ and $85.6 \%$, respectively. They were $26.0^{\circ} \mathrm{C}$ and $84.6 \%$, respectively, in the semi-open building. Thus, the average ambient temperature was $1.4^{\circ} \mathrm{C}$ higher in outdoor conditions (OSP) than in indoor conditions (CSC and CSP).

\section{Growth performance and physiological response}

All production traits were influenced by the type of rearing system, except the body weight at the beginning of the experiment (Table II). Higher body weights and average daily growth rates were observed in CSC pigs, then in CSP pigs, lastly in OSP pigs. The back-fat thickness of pigs was greater in the conventional system (CSC) than in the alternative systems (OSP and CS). Irrespective of the day of measurement, the skin temperature of pigs was higher outside than inside (37.8 vs $\left.35.5^{\circ} \mathrm{C}, \mathrm{p}<0.05\right)$. Skin temperatures were also affected by THI, with higher values observed with high THI. Similarly to the skin temperature, the rectal temperature was greater in OSP pigs than in pigs reared indoors $\left(39.9\right.$ vs $\left.39.6^{\circ} \mathrm{C}\right)$, but the rectal temperature was not affected by THI. It is noteworthy that differences between breeds were also observed for all traits. As expected, the overall growth performance was higher in LW than in CR pigs, but the back-fat thickness was lower in $\mathrm{LW}$ than in CR pigs. The body temperature of the local tropical CR breed was lower than that of the temperate exotic LW breed.

The effect of the interaction between the type of rearing system and the breed was significant for the majority of the studied traits. The average growth rate decreased from CSC to CSP systems by about $29 \%$ and $44 \%$ for CR and LW pigs, respectively. The corresponding values when changing systems from CSC to OSP were about $-54 \%$ and $-62 \%$ for CR and LW pigs, respectively. Skin temperatures increased by about $6 \%$ and $5 \%$ in CR and LW pigs, respectively, when changing system from CSC to OSP. 
Table II

Effect of the system (S) and breed (B) on growth performance and thermoregulatory responses of growing pigs (least square means) (Guadeloupe)

Body weight $(\mathrm{kg})$

Initial

Final

Average daily gain (g)

Back-fat thickness (mm)

Skin temperature $\left({ }^{\circ} \mathrm{C}\right)$

Rectal temperature $\left({ }^{\circ} \mathrm{C}\right)$
Num. of pigs

\section{Creole breed \\ CSC

CSP

9

$$
28.7^{\mathrm{a}}
$$

10

$40.2^{\mathrm{a}}$

$28.9^{a}$

$39.2^{\mathrm{a}}$

$29.8^{\mathrm{a}}$

$480^{\mathrm{a}}$

$340^{\mathrm{b}}$

$34.6^{b}$

$14^{\mathrm{a}}$

gbc

$220^{\mathrm{c}}$

$35.4^{\mathrm{a}}$

$35.0^{\mathrm{b}}$

$15^{\mathrm{a}}$

$39.7^{\mathrm{a}}$ $37.5^{\mathrm{c}}$

$39.9^{\mathrm{c}}$

\begin{tabular}{ccc}
\multicolumn{3}{c}{ Large White breed } \\
CSC & CSP & OSP \\
9 & 10 & 8 \\
& & \\
$30.8^{\mathrm{a}}$ & $31.9^{\mathrm{a}}$ & $31.9^{\mathrm{a}}$ \\
$50.9^{\mathrm{c}}$ & $42.7^{\mathrm{a}}$ & $38.9^{\mathrm{a}}$ \\
$680^{\mathrm{d}}$ & $380^{\mathrm{b}}$ & $260^{\mathrm{c}}$ \\
$10^{\mathrm{b}}$ & $8^{\mathrm{c}}$ & $10^{\mathrm{b}}$ \\
$36.2^{\mathrm{d}}$ & $35.6^{\mathrm{a}}$ & $38.0^{\mathrm{e}}$ \\
$39.7^{\mathrm{a}}$ & $39.9^{\mathrm{c}}$ & $40.0^{\mathrm{c}}$
\end{tabular}

rsd

\section{Statistical analysis}

CSC: indoors, commercial diet; CSP: indoors, sweet-potato diet; OSP: outdoors, sweet-potato diet; THI: temperature humidity index $* \mathrm{p}<0.05 ; * * \mathrm{p}<0.01$

Figure 1 shows the hematocrit of pigs reared in OSC during the second trial. Irrespective of the days of experiment, the hematocrit of outdoor CR pigs was higher than that of outdoor LW pigs, and the CR hematocrit increased after moving $\mathrm{CR}$ pigs from inside to outside. The trend was different in LW pigs with a slight decrease of the LW hematocrit just after the change of systems, and the LW hematocrit increased thereafter.

\section{Outdoor feeding behavior and physical activities}

After four days of adaptation to outdoor conditions, OSP pigs were able to feed themselves by eating sweet-potato leaves and searching tubers. Physical activities were found to be different between breeds (Figure 2). LW pigs were found to be more active ( $40 \%$ of the time spent in physical activities) than CR pigs (30\%). Outdoor feeding behaviors also varied depending on the breed (Figure 3). LW pigs spent much more time eating leaves than CR pigs, conversely CR pigs spent more time eating sweet-potato tubers and the soybean-based protein supplement than LW pigs. CR pigs covered a distance of 90 meters in 24 hours and LW pigs 150 meters $(\mathrm{p}<0.01)$.

\section{Soil characteristics}

Figure 4 shows the density of the macrofauna before and after the pigs were in the field according to their taxonomic groups. After the visits of the pigs to the sweet-potato field, there was an increase in the density of some taxonomic groups, such as Oligochaeta, Dermaptera, Coleoptera adults and larvae, Diptera larvae and Symphyla.

\section{DISCUSSION}

Little is known about the performance of growing pigs in tropical outdoor conditions. Our experimental design, in which pigs from two contrasted breeds (Large White and Creole) were reared either in conventional conditions (building and concentrate feed, CSC) or in alternative conditions (outdoors, OSP ; indoors with feed based on local resources, CSP), contributes to characterize further the outdoor growing pig performance in comparison with other pig systems.

It is admitted that the thermoneutral zone, in which no extra energy is used to maintain thermoregulation, is around $25^{\circ} \mathrm{C}$ for growing pigs (Renaudeau et al., 2007). In the present study, the average ambient temperature in indoor conditions (CSC and CSP) was $26.0^{\circ} \mathrm{C}$ and

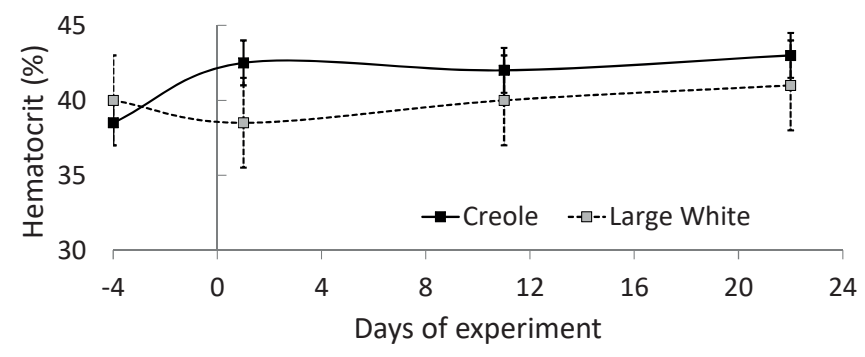

Figure 1: Effect of the breed (Creole vs Large White) on the hematocrit before and after pigs were reared in outdoor conditions in Guadeloupe.

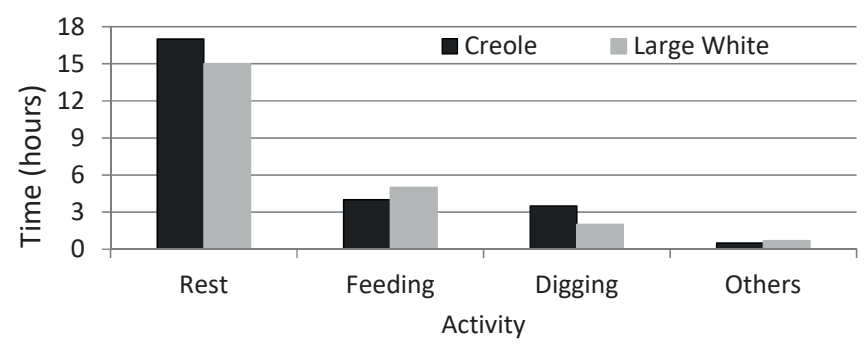

Figure 2: Effect of the breed of growing pigs reared in outdoor systems on physical activities in Guadeloupe.

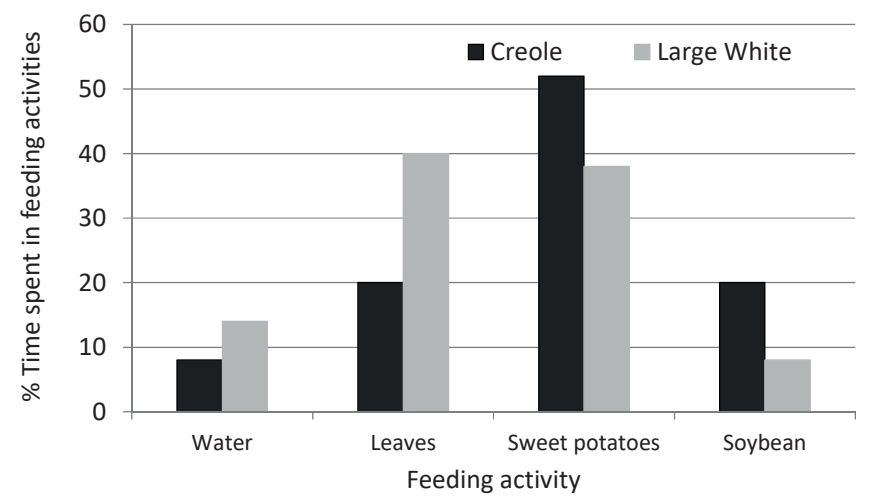

Figure 3: Effect of the breed of growing pigs reared in outdoor systems on the time spent in feeding activities in Guadeloupe. 


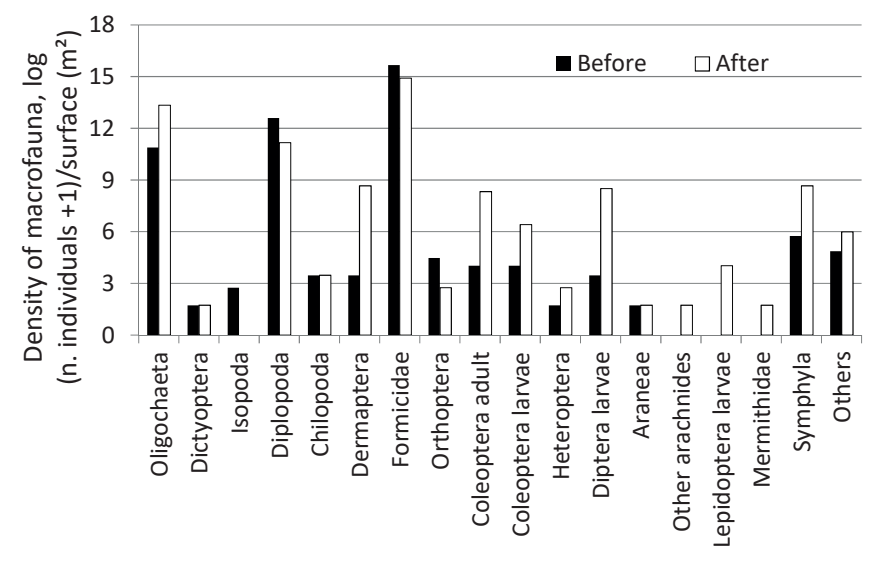

Figure 4: Effect of outdoor pig activities on the density of the macrofauna in Guadeloupe.

$27.4^{\circ} \mathrm{C}$ in outdoor conditions (OSP). Consequently, irrespective of the rearing systems, pigs in the current study were heat stressed, and OSP pigs were more heat stressed than indoor pigs.

The growth performance of CSC pigs was in the range of values generally reported for Creole and Large White pigs at this stage of production (Renaudeau et al., 2006) with a lower growth rate and higher back-fat thickness in CR pigs than in LW pigs. At the end of the 28-day experiment, we observed a significant breed effect in the body weight of pigs reared in a same system. It was due to differences in the growth rate between breeds in a given system. In addition, CR pigs had higher back-fat thickness than LW pigs. These results agree with those obtained in indoor 45-kilogram pigs by Renaudeau et al. (2006). This is because the Creole breed has never been genetically improved. Its growing performance is lower than that of the Large White breed, which has been a major maternal breed used in commercial breeding schemes worldwide for more than 30 years for its lean tissue growth rate and reproductive capacity (Whittemore, 2006).

Irrespective of the breed, OSP pigs had a lower growth performance than pigs reared in CSC or CSP. Given that animals in OSP and CSP had a similar feed intake, a higher physical activity in OSP compared to CSP may explain such differences. Based on Noblet (2005), metabolizable energy (ME) of OSP and CSP diets (considered as identical) as well as maintenance requirements in ME have been calculated. Based on data from behavior studies, the ME required for additional physical activity in outdoor conditions was estimated to be around 6\%. Thus, available ME for production was reduced. Indeed, in OSP and CSP conditions, with the energy and protein feed allowance, pigs should have theoretically achieved a growth rate of $500 \mathrm{~g} /$ day for CR and 800 $\mathrm{g}$ /day for LW pigs. The growth rate was $32 \%$ and $52 \%$ lower in CSP than what was expected for CR and LW pigs, respectively. In OSP conditions, the reduction in the growth rate was about $56 \%$ and $68 \%$ for CR and LW pigs, respectively. Consequently, it can be suggested that a part of the available energy of the feed was lost in additional physical activities including digging in OSP and mastication efforts in the ingestion of sweet potatoes (CSP and OSP). It is difficult to evaluate the extent to which climatic parameters have influenced ME utilization but they may have played an important role. Furthermore, in heat-stressed conditions, pigs reduce feed intake in order to reduce thermogenesis and heat stress (Collin et al., 2001). It could be suggested that a part of the available energy in OSP and CSP was not used to avoid extra-heat production from the metabolic effect of feed intake.

Outdoor pigs had greater body temperatures than indoor pigs. This was explained by an average difference in ambient temperature of $+1.4^{\circ} \mathrm{C}$ between outdoors and a semi-open building. Breed, with lower values in CR than in LW pigs, significantly affected skin temperatures. Our findings agreed with previous results comparing the acclimation of LW and CR growing pigs to a hot environment (Renaudeau et al., 2007). In tropical and subtropical areas, a microevolution has promoted the emergence of breeds with a high ability to cope with heat stress (Naves et al., 2011). The Creole pig has a unique combination of genes from European breeds brought by European colonists during the 16th century (FAO, 2007).

In agreement with the study of Renaudeau et al. (2005), the ingestion time of soybean meal was more important in CR than in LW pigs. The difference in outdoor behavior between breeds suggests that some differences occurred between CR and LW adaptation strategies in outdoor conditions. A study on outdoor reared Iberian pigs showed that animals spent more than $60 \%$ of their daily time in explorative activity (Rodriguez-Estévez et al., 2009). This value is much higher than the one obtained in the current study as LW and CR spent respectively $15 \%$ and $10 \%$ of their daily time in explorative activity. Differences in climatic parameters may be an explanation. Indeed in Rodriguez-Estévez' study, the average ambient temperature was $7^{\circ} \mathrm{C}$, whereas in this study it was $27.4^{\circ} \mathrm{C}$ : a high ambient temperature generally decreases the physical activities and increases the time to rest in order to promote heat loss. The quality of the pasture may also be an explanation. In the present experiment, animals were conducted on a cultivated field, dense in sweet-potato tubers. Rodriguez' study was performed on a dehesa, a multifunctional agro-sylvo-pastoral system, which is more scattered.

Our findings on the physiological responses from the blood profiles highlighted the better adaptation of the local breed (CR pig) when they swapped from indoor to outdoor systems. The adaptive hematological response was faster in CR pigs than in the exotic breed (LW pigs). Unlike CR pigs, the arrival of exotic pigs in outdoor conditions caused firstly a weakening of their hematological status suggesting that LW pigs were stressed by the change. This kind of result is rare in the literature but, considering the number of individuals (four per breed), it should be interpreted with caution. Further data are needed to confirm the better adaptation to change of $\mathrm{CR}$ pigs in rearing systems.

Regarding the interaction between pig digging and the macrofauna in our experimental conditions, the presence of pigs on the plots (manure) seemed beneficial to the soil macrofauna, thus improving the quality of the land for future crops. Indeed, the macrofauna before and after OSP pigs' activities showed an increase in invertebrate decomposers (Oligochaeta, Dermaptera, etc.). This result must be taken with caution because in our experimental conditions the discovery of plots was gradual, the grazing period was only about 28 days and the density of pigs was low. Consequently, the negative impact of pigs was probably underestimated in the present study.

\section{CONCLUSION}

The alternative systems (outdoors and/or diet based on local resources), although less efficient from a zootechnical point of view, should appeal to breeders of mixed farming systems who are looking for an economic gain in animal production by using crop residues and minimizing human intervention. The study shows that in the framework of mixed farming systems, pigs can provide ecological services. For instance, pigs can valorize a sweet-potato field or any crop residues that cannot be commercialized (but that are still edible) because of damages by weevils or nematodes. They can thus reduce the use of herbicides and tillage before planting the next following crop. This study is part of trials that aim at meeting mixed farming requirements in terms of technical-economic references in outdoor pig systems, and alternatives to preserve and develop a niche market for the local pig breed. 


\section{Acknowledgments}

The financial support of the European Union funds (FEDER, FSE) and Guadeloupe Region (including the AGROECODIV project) are gratefully acknowledged. The authors are extremely grateful to $\mathrm{Mr}$. George Magdeleine for his technical support and his precious help during this experiment.

\section{REFERENCES}

Baudet M., Archimède H., Giorgi M., Beramice D., Bructer M., Gourdine J.-L., 2015. Effet de la conduite d'élevage et du type génétique sur les performances du porc à l'engraissement élevé en milieu tropical humide. Journ. Rech. Porcine, 47 : 253-254

Burel A., Archimède H., Mahieu M., Fanchone A., Gourdine J.-L., 2013. Foraging behavior of Creole pigs kept outdoor under tropical conditions on sweet potatoes field. In: Annual meeting of the European Association for Animal Production. EAAP, Nantes, France, 26-30 Aug. 2013

Collin A., van Milgen J., Dubois S., Noblet J., 2001. Effect of high temperature and feeding level on energy utilization in piglets. J. Anim. Sci., 79: 1849-1857, doi: 10.2527/2001.7971849x

FAO, 2007. The state of the world's animal genetic resources for food and agriculture (Ed. Pilling B.R.D.). FAO, Rome, Italy, 511 p.

FAOSTAT, 2015. FAO, Rome, Italy, www.fao.org/faostat/en/\#data/QL (accessed 25 June 2017)

Gourdine J.-L., Renaudeau D., Xandé X., Régnier C., Anaïs C., Alexandre G., Archimède $H_{\text {., }}$ 2011. Production systems valorizing local resources in pig production in tropical areas. Innov. Agron.,15: 75-87

Naves M., Alexandre G., Mahieu M., Gourdine J.-L., Mandonnet N., 2011 Animal local genetic resources: basis of innovating and sustainable animal production systems in French West Indies. Innov. Agron., 15: 193-205

\section{Résumé}

Gourdine J.-L., Bambou J.-C., Giorgi M., Loranger-Merciris G., Archimède $\mathbf{H}$. Performances des porcs en croissance élevés en plein air sur des parcelles de patates douces

L'étude a été menée afin d'évaluer l'effet du type génétique (Large White [LW] vs Créole [CR]) et la conduite alimentaire (en bâtiment avec du concentré [BC], en plein air sur parcelles de patates douces [PPD], en bâtiment avec une ration identique au plein air [BPD]) sur 54 porcs en croissance. Les animaux PPD ont eu une vitesse de croissance de 240 grammes par jour, comparée à 360 et $580 \mathrm{~g} / \mathrm{j}$ respectivement pour les porcs BPD et BC $(p<0,001)$. En plein air, les LW ont eu une activité physique plus importante que les CR (respectivement $15 \%$ du temps aux activités exploratrices vs $10 \%, p<0,01$ ). Les distances parcourues pendant 24 heures ont été de 90 mètres chez les CR et de 150 mètres chez les LW $(p<0,01)$. Les profils sanguins ont suggéré une réponse adaptative hématologique plus rapide des CR au changement de système (du bâtiment au plein air). L'étude de la macrofaune du sol après passage des animaux a montré une augmentation des macroinvertébrés décomposeurs (notamment Oligochaeta, Dermaptera) sur les parcelles pâturées. Cette étude suggère que les élevages alternatifs, quoique moins performants, pourraient convenir aux paysans recherchant un gain économique sur une production animale, en utilisant les résidus agricoles ou en minimisant l'intervention humaine.

Mots-clés : porcin, élevage, système d'élevage, alimentation des animaux, croissance, patate douce, Guadeloupe
Noblet J., 2005. Protein and energy requirements of growing swine. In: Proc. Int. Symp. Nutritional requirements of poultry and swine (Eds. Rostagno H.S., Teixeira Albinoid L.F.), Viçosa, MG, Brasil. Universidade Federal, Viçosa, Brazil, 175-198

Noblet J., Sève B., Jondreville C., 2004. Nutritional values for pigs. In: Tables of composition and nutritional value of feed materials: pigs, poultry, cattle, sheep, goats, rabbits, horses, fish (Eds. Sauvant D., Perez J.M., Tran G.). INRA, Versailles, France, 25-35

Régnier C., 2011. Valorisation des ressources alimentaires tropicales (feuilles et tubercules) chez le porc. Thèse Doct., Université des Antilles et de la Guyane, Guadeloupe, $111 \mathrm{p}$.

Renaudeau D., Giorrgi M., Silou F., Weisbecker J.-L., 2006. Effect of breed (lean or fat pigs) and sex on performance and feeding behaviour of group housed growing pigs in a tropical climate. Asian-Aust. J. Anim. Sci., 19: 593-601, doi: 10.5713/ajas.2006.593

Renaudeau D., Gourdine J.-L., Anais C., 2007. Thermoregulatory responses to high ambient temperature in growing pigs: effects of temperature level and breed. In: Animal housing in hot climates, Cairo, Egypt, 1-4 Apr. 2007, 1-31

Renaudeau D., Hilaire M., Mourot J., 2005. A comparison of growth performance, carcass and meat quality of Creole and Large White pigs slaughtered at 150 days of age. Anim. Res., 54: 43-54, doi: 10.1051/ animres:2004042

Rodriguez-Estévez V., Garcia A., Pena F., Gomez A.G., 2009. Foraging of Iberian fattening pigs grazing natural pasture in the dehesa. Livest. Sci., 120 (1-2): 135-143, doi: 10.1016/j.livsci.2008.05.006

Whittemore C.T., 2006. Development and improvement of pigs by genetic selection. In: Science and practice of pig production (Eds. Whittemore C.T., Kyriazakis I.). Blackwell Publishing, Oxford, UK, 184-261, doi: 10.1002/9780470995624.ch6

Zumbach B., Misztal I., Tsuruta S., Sanchez J.P., Azain M., Herring W., Holl J., et al., 2008. Genetic components of heat stress in finishing pigs: Development of a heat load function. J. Anim. Sci., 86: 2082-2088, doi: 10.2527/jas.2007-0523

\section{Resumen}

Gourdine J.-L., Bambou J.-C., Giorgi M., Loranger-Merciris G., Archimède $\mathbf{H}$. Rendimiento de cerdos en crecimiento criados en interior o en exterior en campos de patata dulce

El presente estudio tuvo como objetivo de evaluar el efecto del tipo genético (Gran Blanco o Large White [LW] vs criollo [CR]) y el manejo alimenticio (en interior con concentrado $[\mathrm{BC}]$, exterior en lotes de patata dulce [PPD], en interior con la misma ración que en exterior [BPD]), en 54 cerdos en crecimiento. Los animales PPD tuvieron una tasa de crecimiento de 240 gramos por día, contra 360 y 580 g/d para los cerdos BPD y $B C$, respectivamente $(p<0,001)$. En exterior, los LW fueron físicamente más activos que los CR (15\% del tiempo en actividades exploratorias vs $10 \%$ respectivamente, $p<0,01)$. Las distancias recorridas en 24 horas fueron 90 metros para los CR y 150 para los LW $(p<0,01)$. Los perfiles sanguíneos sugieren una respuesta hematológica adaptativa más rápida de los CR a los cambios de sistema (de interior a exterior). El estudio de la macrofauna del suelo después del pasaje de los animales por los lotes pastoreados mostró un aumento de macro invertebrados (particularmente Oligochaeta, Dermaptera) que descomponen materia orgánica. Este estudio sugiere que los sistemas de ganadería alternativos, aunque menos eficientes, podrían ser adecuados para los finqueros en busca de ganancia económica en la producción animal, mediante el uso de residuos agrícolas o minimizando la intervención humana.

Palabras clave: cerdo, ganadería, sistema de cría, alimentación de los animales, crecimiento, batata, Guadalupe 